\title{
Pola Pertumbuhan dan Produksi $\alpha$-Amilase Bacillus amyloliquefaciens pada Substrat Pati Jagung dengan Variasi pH Awal Media dan Waktu Inkubasi
}

\section{Growth and Production of Bacillus amyloliquefaciens $\alpha$-Amylase on Corn Starch Substrat with Variation of Initial pH Medium and Incubation Time}

\author{
Sisilia Sri Wahyuningsih ${ }^{1}$, E. Mursyanti ${ }^{1 *}$ dan P. Kianto Atmodjo ${ }^{1}$ \\ ${ }^{1}$ Fakultas Biologi, Universitas Atma Jaya Yogyakarta, Jl. Babarsari 44 Yogyakarta 55281. \\ E-mail : santi_em@mail.uajy.ac.id.*Penulis untuk korespondensi.
}

\begin{abstract}
The aims of this study were to identify the growth curve of B. amyloliquefaciens on cornstarch and non corn starch addition media, number of cells and production of $\alpha$-amylase on variety initial pH during the stationary phase. The growth curve of $B$. amyloliquefaciens was made using the water optical density on both medium which has inoculated by microbes. The experimental design for the $\alpha$-amylase production was factorial completely randomized design $(6 \times 3 \times 3)$. There were two factors included in this study i.e. initial $\mathbf{p H}$ of the media ( 5, 5.5, 6, 6.5, 7 and 7.5) and incubation times (16, 18 and 20 hours). The results showed that $B$. amyloliquefaciens growth curve on medium with corn starch was slower than on medium without corn starch. Production of $\alpha$-amylase and number of cells were having similar patterns in all treatments, i.e. increased until optimum $\mathrm{pH}$ and incubation time were reached. The number of cells and $\alpha$-amylase production were optimal at pH 6.5 for 18 hours incubation whereas the number of cells (about $2.8542 \times 10^{8}$ cells/ml) and $\alpha$-amylase production $(1.4467$ units/ml) were optimal at pH 6.5 for 18 hours incubation.
\end{abstract}

Key words : $\quad$ B. amyloliquefaciens, $\alpha$-amylase, corns starch medium, initial pH

Diterima: 8 Oktober 2003, disetujui: 2 Maret 2004

\section{Pendahuluan}

Alfa-amilase ( $\alpha-1,4$ glukan-4 glukanohidrolase) merupakan enzim yang banyak terdapat dalam jaringan tumbuhan, mammalia, dan mikrobia (Whitaker, 1972). Enzim ini mampu menghidrolisis pati secara random dari bagian dalam atau tengah molekul sehingga menghasilkan gula reduksi (Kulp, 1975). Alfaamilase juga merupakan enzim yang mempunyai peranan yang besar dalam bidang industri, seperti pada industri kertas dan alkohol dalam proses liquifikasi pati. Di samping itu, digunakan pula pada industri pakan ternak untuk membantu hidrolisis gandum (Crueger and Crueger, 1990).

B. amyloliquefaciens merupakan salah satu jenis mikrobia yang mampu memproduksi $\alpha$-amilase dalam jumlah besar melalui liquifikasi pati dengan menghasilkan maltosakarida dan glukosa (Gibson and Gordon, 1975) Alfa-amilase yang dihasilkan oleh B. amyloliquefaciens bersifat ekstraseluler dan banyak diproduksi selama fase stationer (Frost and Moss, 1987; Moat and Foster, 1988 Crueger and Crueger 1990; Ginting, 2003). 
Produksi $\alpha$-amilase $B$. amyloliquefaciens dipengaruhi oleh beberapa faktor lingkungan, antara lain $\mathrm{pH}$. Derajat keasaman $(\mathrm{pH})$ sangat mempengaruhi aktivitas enzim yang diproduksi karena dapat merubah konformasi enzim dan kestabilan komplek enzim-substrat (ES) (Mulyadi, 1990). Menurut Wibowo (1989), pH optimum untuk produksi enzim ekstraseluler termasuk $\alpha$-amilase hampir sama dengan $\mathrm{pH}$ optimum untuk pertumbuhan sel.

Tujuan penelitian ini adalah untuk mengetahui bagaimana pola pertumbuhan $B$. amyloliquefaciens pada substrat pati jagung dan pengaruh variasi $\mathrm{pH}$ awal media terhadap jumlah sel dan produksi $\alpha$-amilase $B$. amyloliquefaciens selama fase stasioner. Hasil penelitian ini diharapkan dapat memberikan informasi mengenai $\mathrm{pH}$ optimum untuk pertumbuhan $B$. amyloliquefaciens dan memproduksi $\alpha$-amilase serta waktu inkubasi yang tepat untuk memanen $\alpha$-amilase.

\section{Metode Penelitian}

\section{Uji Kemurnian B. amyloliquefaciens}

Biakan murni B. amyloliquefaciens FNCC-079 yang diperoleh dari Laboratorium Mikrobiologi PAU Pangan dan Gizi UGM, Yogyakarta, diambil 1 ose dan diinokulasi ke medium nutrien agar miring (NA), selanjutnya diinkubasi selama 24 jam pada suhu $37^{\circ} \mathrm{C}$. Koloni yang tumbuh kemudian diinokulasi ke medium selektif Bacillus cereus agar (BCA) dan medium Blood agar plate (BAP) secara goresan. Koloni yang tumbuh diamati, kemudian dilakukan pengecatan Gram dan uji biokimiawi (Logan and Turnbull, 1999; Priest et al., 1987).

\section{Pembuatan Starter Bakteri}

Biakan murni B. amyloliquefaciens dalam medium NA miring yang berumur 24 jam diambil 1 ose dan diinokulasi ke dalam 20 $\mathrm{ml}$ medium pertumbuhan dengan komposisi (w/v) $5 \%$ pati jagung, $0,56 \% \mathrm{NH}_{4} \mathrm{NO}_{3}, 0,05 \%$ $\mathrm{CaCl}_{2} .2 \mathrm{H}_{2} \mathrm{O}, 0,13 \% \quad \mathrm{KH}_{2} \mathrm{PO}_{4}, 0,28 \%$ Natrium sitrat, $0,5 \%$ pepton dan $0,2 \%$ ekstrak khamir. Inkubasi dilakukan selama 24 jam pada suhu $30^{\circ} \mathrm{C}$ dalam shaker incubator dengan kecepatan 150 rotasi per menit (rpm) (Crueger and Crueger, 1990 yang dimodifikasi).

\section{Pembuatan Kurva Pertumbuhan $B$.} amyloliquefaciens

Starter $1 \% \quad(\mathrm{v} / \mathrm{v})$ diinokulasikan ke dalam $150 \mathrm{ml}$ medium pertumbuhan yang ditambah 5\% pati jagung dan ke dalam $150 \mathrm{ml}$ medium pertumbuhan tanpa pati jagung. Masing-masing diinkubasi dalam shaker incubator dengan kecepatan $150 \mathrm{rpm}$ selama 24 jam pada suhu $30^{\circ} \mathrm{C}$ dan $\mathrm{pH}$ 6,5. Setiap 2 jam sekali, mulai jam ke-0 dilakukan pengukuran optical density (OD) dengan menggunakan spektrofotometer dengan panjang gelombang $600 \mathrm{~nm}$ dan $\mathrm{pH}$ media dengan menggunakan $\mathrm{pH}$ meter.

\section{Pengaruh Variasi pH Awal Media Terhadap Produksi $\alpha$-Amilase B. amyloliquefaciens}

Starter $1 \%(\mathrm{v} / \mathrm{v})$ diinokulasi ke media pertumbuhan yang ditambah $5 \%$ pati jagung dengan variasi $\mathrm{pH}$ awal medium $5 ; 5,5 ; 6 ; 6,5$; 7 dan 7,5. Pengukuran dilakukan selama fase stasioner yang meliputi jumlah sel, produksi $\alpha-$ amilase dan $\mathrm{pH}$ medium. Jumlah sel dihitung secara langsung dengan menggunakan hemasitometer dan $\alpha$-amilase yang diproduksi dihitung dengan mengukur kadar gula reduksi yang dihasilkan (Crueger and Crueger, 1990 yang dimodifikasi).

\section{Preparasi Enzim Kasar}

Sampel dari medium pertumbuhan diambil $10 \mathrm{ml}$, kemudian disentrifugasi dengan kecepatan $4000 \mathrm{rpm}$ selama 30 menit. Supernatan yang merupakan enzim kasar diambil untuk dianalisis aktivitasnya (Dirnawan et al., 2000).

6. Pengujian Aktivitas dan Penentuan Jumlah $\alpha$-Amilase yang Diproduksi

Tabung reaksi diisi $0,5 \mathrm{ml}$ larutan enzim, $0,25 \mathrm{ml}$ buffer fosfat $\mathrm{pH} 6,5$ dan 0,25 ml larutan amilum 5\%, kemudian diinkubasi pada suhu $30^{\circ} \mathrm{C}$ selama 30 menit. Reaksi dihentikan dengan melakukan pemanasan dalam air mendidih selama 5 menit (Riswahyuli, 2000). Jumlah $\alpha$-amilase yang 
diproduksi oleh $B$. amyloliquefaciens diukur dengan menggunakan pendekatan aktivitas $\alpha$-amilase, yaitu dengan mengukur jumlah gula reduksi yang dihasilkan dengan metode dinitrosalicylic acid (DNS). Satu unit aktivitas $\alpha$-amilase didefinisikan sebagai jumlah enzim yang mengkatalisis reaksi dengan melepaskan $1 \mu$ mol gula reduksi yang setara dengan glukosa tiap menit di bawah kondisi uji (Mammo and Gessesse, 1999).

\section{Rancangan Percobaan dan Analisis Data}

Penelitian ini menggunakan rancangan acak lengkap dengan pola faktorial. Hasil yang diperoleh dianalisis menggunakan ANAVA dan uji Duncan Multiple Range Test (DMRT) pada taraf kepercayaan $95 \%$.

\section{Hasil dan Pembahasan}

\section{Uji Kemurnian B. amyloliquefaciens}

Berdasarkan hasil uji kemurnian terhadap kultur B. amyloliquefaciens (Tabel 1) dapat diketahui bahwa kultur yang digunakan mempunyai sifat morfologi koloni, bentuk sel dan sifat gram serta sifat-sifat biokimia yang sesuai dengan sifat $B$. amyloliquefaciens menurut Logan and Turnbull (1999) dan Priest et al. (1987). Dengan demikian kultur yang digunakan adalah murni B. amyloliquefaciens dan dapat digunakan untuk tahap penelitian berikutnya.

2. Pengaruh Penambahan Pati Jagung Terhadap Pola Pertumbuhan $B$. amyloliquefaciens

Pola pertumbuhan B. amyloliquefaciens dalam medium tanpa dan dengan penambahan 5\% pati jagung dapat dilihat pada Gambar 1 . Berdasarkan grafik tersebut dapat dilihat bahwa pertumbuhan $B$. amyloliquefaciens dalam medium dengan penambahan pati jagung lebih lambat dibandingkan pertumbuhan $B$. amyloliquefaciens dalam medium tanpa pati jagung.Hal ini terjadi karena energi yang dihasilkan oleh sel bakteri dalam medium dengan pati jagung digunakan untuk pertumbuhan sel dan sebagian lagi untuk produksi $\alpha$-amilase, karena keberadaan pati jagung dalam medium akan memacu sel-sel B. amyloliquefaciens untuk menghasilkan $\alpha$-amilase. Secara umum pola pertumbuhan B. amyloliquefaciens dalam medium dengan penambahan pati jagung dan dalam medium tanpa penambaha pati jagung menunjukkan perbedaan seperti yang terlihat pada Gambar 1 .

Gambar 2 menunjukkan bahwa pertumbuhan $B$. amyloliquefaciens dalam medium tanpa maupun dengan penambahan pati jagung juga diikuti dengan perubahan $\mathrm{pH}$ medium yang cenderung menjadi basa. Perubahan ini terjadi karena medium yang kompleks ketika diinokulasi dengan mikrobia selama kurun waktu inkubasi tertentu akan mengalami perubahan komposisi medium secara terus menerus, sehingga $\mathrm{pH}$ medium juga berubah sebagai hasil dari aktivitas metabolisme sel yang mengkonsumsi substrat dengan menghasilkan substansi yang dapat menyebabkan perubahan $\mathrm{pH}$ menjadi asam atau basa (Madigan et al., 2000; Ginting, 2003).

3. Pengaruh Variasi $\mathrm{pH}$ Awal Medium Terhadap Jumlah Sel dan Aktivitas $\alpha-$ Amilase B. amyloliquefaciens

Alfa-amilase merupakan enzim yang banyak diproduksi selama fase stasioner karena gen regulator untuk pembentukan $\alpha$-amilase, yaitu amyE diekspresikan pada konsentrasi glukosa dalam medium rendah (Fisher and Sonenshein, 1991). Berdasarkan pola pertumbuhan B. amyloliquefaciens diketahui bahwa fase stasioner terjadi antara jam ke-16 sampai jam ke-20.

Perlakuan variasi $\mathrm{pH}$ awal medium yang diamati pada tiga titik selama fase stasioner (jam ke-16, 18, dan 20) ternyata mempengaruhi jumlah sel dan aktivitas $\alpha$ amilase yang diproduksi. Tabel 2 menunjukkan bahwa jumlah sel yang dihasilkan berbeda pada setiap perlakuan. 
Tabel 1. Ciri morfologi dan sifat biokimia B. amyloliquefaciens

\section{Karakteristik}

Keterangan

A. Morfologi koloni pada medium :

1. Nutrien Agar Miring (NA)

2. Blood Agar Plate (BAP)

3. Bacillus Cereus Agar (BCA)

B. Bentuk sel dan sifat Gram
Koloni berwarna putih dan tumbuh lebat.

Koloni berbentuk sirkuler, berwarna merah dan mampu melakukan hemolisis darah.

Koloni berwarna kehijauan dan dikelilingi 2 zona.

Berbentuk batang dan bersifat Gram positif.

\section{Sifat Biokimia}

1. Produksi asam dari :
a. glukosa
b. laktosa
c. manitol
d. maltosa
e. sukrosa
f. arabinosa
g. silosa

2. Penggunaan sitrat sebagai sumber karbon

3. Hidrolisis gelatin

4. Reduksi nitrat menjadi nitrit

5. Motilitas

6. Produksi indol

7. Produksi $\mathrm{H}_{2} \mathrm{~S}$

8. Arginin dihidrolase

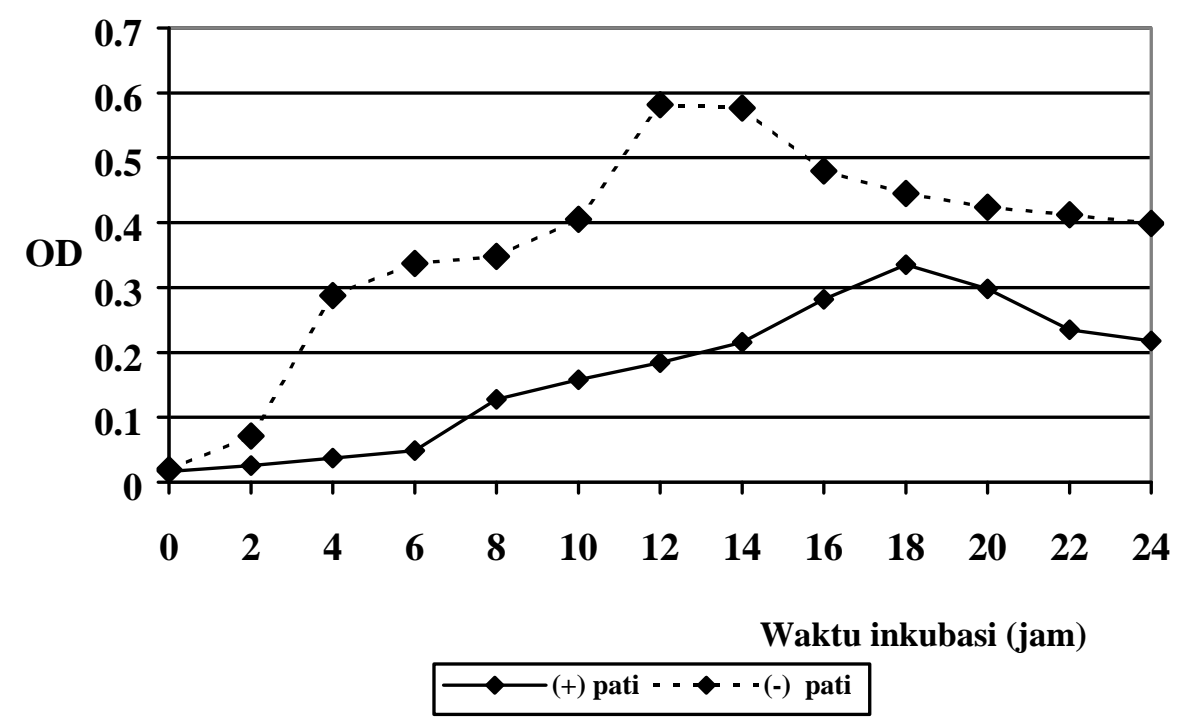

Gambar 1. Kurva pertumbuhan B. amyloliquefaciens dalam medium pertumbuhan dengan dan tanpa penambahan pati jagung. 


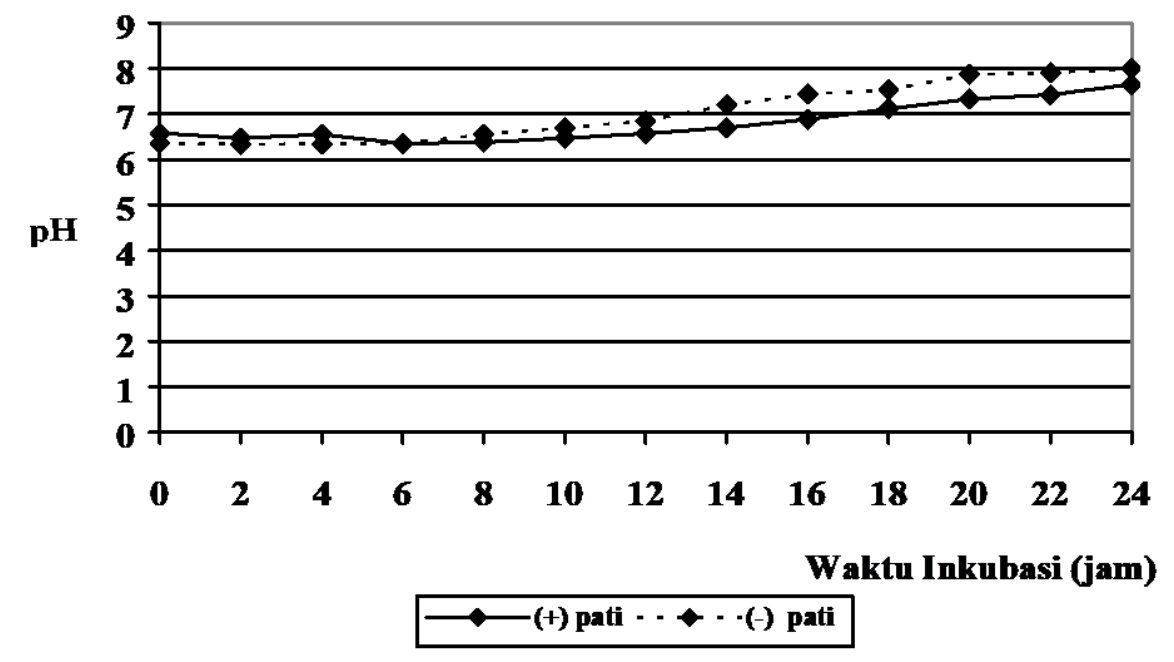

Gambar 2. Perubahan pH medium pertumbuhan B. amyloliquefaciens.

Tabel 2. Pengaruh variasi $\mathrm{pH}$ awal medium terhadap perubahan $\mathrm{pH}$ medium, jumlah sel, aktivitas $\alpha$-amilase $B$. amyloliquefaciens selama fase stasioner (jam ke-16, 18 dan 20).

\begin{tabular}{|c|c|c|c|c|}
\hline $\begin{array}{l}\text { Waktu Inkubasi } \\
\text { (Jam ke-) }\end{array}$ & pH Awal Medium & pH Akhir & $\begin{array}{c}\text { Jumlah Sel } \\
\left(x 1^{8} \mathrm{sel} / \mathrm{ml}\right)\end{array}$ & $\begin{array}{c}\text { Aktivitas } \alpha \text {-Amilase } \\
\text { (Unit/ml larutan enzim) }\end{array}$ \\
\hline \multirow{6}{*}{16} & 5 & $5,3600^{\circ}$ & $1,3542^{\mathrm{i}}$ & $0,2618^{\mathrm{i}}$ \\
\hline & 5,5 & $5,8500^{1}$ & $1,8125^{\mathrm{h}}$ & $0,4159^{i}$ \\
\hline & 6 & $6,3900^{\mathrm{j}}$ & $2,1458^{\mathrm{e}}$ & $0,6881^{\mathrm{f}}$ \\
\hline & 6,5 & $6,9000^{\mathrm{g}}$ & $2,6548^{\mathrm{b}}$ & $1,0744^{\mathrm{c}}$ \\
\hline & 7 & $7,2450^{\mathrm{f}}$ & $2,2708^{\mathrm{d}}$ & $0,8202^{\mathrm{e}}$ \\
\hline & 7,5 & $7,6550^{c}$ & $1,6666^{\mathrm{h}}$ & $0,3699^{i}$ \\
\hline \multirow[t]{6}{*}{18} & 5 & $5,5500^{\mathrm{n}}$ & $1,7708^{\mathrm{h}}$ & $0,4079^{\mathrm{i}}$ \\
\hline & 5,5 & $6,1300^{\mathrm{k}}$ & $2,0417^{\mathrm{f}}$ & $0,6981^{\mathrm{f}}$ \\
\hline & 6 & $6,6150^{\mathrm{i}}$ & $2,4167^{c}$ & $0,8822^{\mathrm{e}}$ \\
\hline & 6,5 & $7,1950^{\mathrm{f}}$ & $2,8542^{\mathrm{a}}$ & $1,4467^{a}$ \\
\hline & 7 & $7,3250^{\mathrm{e}}$ & $2,6042^{\mathrm{b}}$ & $1,0664^{\mathrm{c}}$ \\
\hline & 7,5 & $7,7650^{\mathrm{b}}$ & $1,8542^{\mathrm{h}}$ & $0,5820^{\mathrm{i}}$ \\
\hline \multirow[t]{6}{*}{20} & 5 & $5,7400^{\mathrm{m}}$ & $1,3958^{\mathrm{i}}$ & $0,3358^{\mathrm{i}}$ \\
\hline & 5,5 & $6,4000^{\mathrm{j}}$ & $1,9167^{\mathrm{g}}$ & $0,5000^{\mathrm{h}}$ \\
\hline & 6 & $6,8050^{\mathrm{h}}$ & $2,3125^{\mathrm{d}}$ & $0,8242^{\mathrm{e}}$ \\
\hline & 6,5 & $7,3150^{\mathrm{e}}$ & $2,7500^{\mathrm{b}}$ & $1,2245^{\mathrm{b}}$ \\
\hline & 7 & $7,4500^{\mathrm{d}}$ & $2,3750^{c}$ & $0,9223^{\mathrm{d}}$ \\
\hline & 7,5 & $7,9200^{\mathrm{a}}$ & $1,6666^{\mathrm{h}}$ & $0,3939^{\mathrm{i}}$ \\
\hline
\end{tabular}

Keterangan : Notasi huruf yang sama dalam kolom menunjukkan tidak ada beda nyata pada $\alpha: 5 \%$.

Gambar 3 menunjukkan bahwa pola pertumbuhan B. amyloliquefaciens pada semua perlakuan mempunyai pola yang hampir sama, yaitu tertinggi pada jam ke-18, kemudian diikuti jam ke-20 dan terendah pada jam ke-16. Gambar 3 juga menunjukkan bahwa kisaran pH awal medium antara 6-7 menghasilkan 
jumlah sel yang cukup tinggi, terutama pada pH awal 6,5, yaitu sebesar 2,8542 x $10^{8} \mathrm{sel} / \mathrm{ml}$.

Hasil yang tersaji dalam Tabel 3 dan Gambar 4 menunjukkan bahwa aktivitas $\alpha$ amilase tertinggi dicapai pada $\mathrm{pH}$ awal medium 6,5 dan pada jam ke-18, yaitu sebesar $1,4467 \mathrm{unit} / \mathrm{ml}$ larutan enzim. Hal ini berarti $\mathrm{pH}$ awal medium 6,5 merupakan $\mathrm{pH}$ yang optimum untuk memproduksi $\alpha$-amilase dengan aktivitas yang tinggi, karena kecepatan aktivitas katalitik enzim dengan substrat untuk menghasilkan produk juga optimum (Garret and Grisham, 1995). Hasil tersebut juga sesuai dengan beberapa penelitian yang dilakukan oleh Dobreva et al. (1994) dan Mammo and Gessesse (1999) yang mengungkapkan bahwa $\alpha$-amilase yang dihasilkan oleh mikrobia yang menghidrolisis pati dengan proses liquifikasi aktif pada $\mathrm{pH}$ mendekati netral. Aktivitas $\alpha$ amilase pada $\mathrm{pH}$ 6,5 dan jam ke-18 tinggi karena jumlah sel penghasilnya besar (Achi and Ngoku-Obi, 1992).

Aktivitas $\alpha$-amilase yang diproduksi mempunyai pola yang hampir sama yaitu mengalami kenaikan sampai jam ke-18 dan mulai turun pada jam ke-20 (Gambar 4). Hal ini terjadi karena adanya penumpukan produk akhir yang lebih sederhana, seperti glukosa dan maltosa yang dapat menekan pembentukkan $\alpha$ amilase (Mubarik et al., 2003)
Penurunan produksi $\alpha$-amilase juga dapat disebabkan oleh perubahan $\mathrm{pH}$ medium yang cenderung menjadi basa pada semua perlakuan (Gambar 5). Perubahan $\mathrm{pH}$ ini terjadi sebagai akibat dari aktivitas metabolisme sel mikrobia yang mengkonsumsi substrat dalam medium. Perubahan $\mathrm{pH}$ medium ini akan mempengaruhi kemampuan mikrobia dalam mensintesis enzim (Ginting, 2003). Berdasarkan hasil penelitian ini juga diketahui bahwa kisaran $\mathrm{pH}$ medium yang optimum untuk produksi $\alpha$-amilase dan pertumbuhan adalah 6,5 - 7,5 dan di luar kisaran tersebut aktivitas $\alpha$-amilase yang dihasilkan kurang optimum.

Penurunan produksi $\alpha$-amilase juga dapat disebabkan oleh perubahan $\mathrm{pH}$ medium yang cenderung menjadi basa pada semua perlakuan (Gambar 5). Perubahan $\mathrm{pH}$ ini terjadi sebagai akibat dari aktivitas metabolisme sel mikrobia yang mengkonsumsi substrat dalam medium. Perubahan $\mathrm{pH}$ medium ini akan mempengaruhi kemampuan mikrobia dalam mensintesis enzim (Ginting, 2003). Berdasarkan hasil penelitian ini juga diketahui bahwa kisaran $\mathrm{pH}$ medium yang optimum untuk produksi $\alpha$-amilase dan pertumbuhan adalah 6,5 - 7,5 dan di luar kisaran tersebut aktivitas $\alpha$-amilase yang dihasilkan kurang optimum.

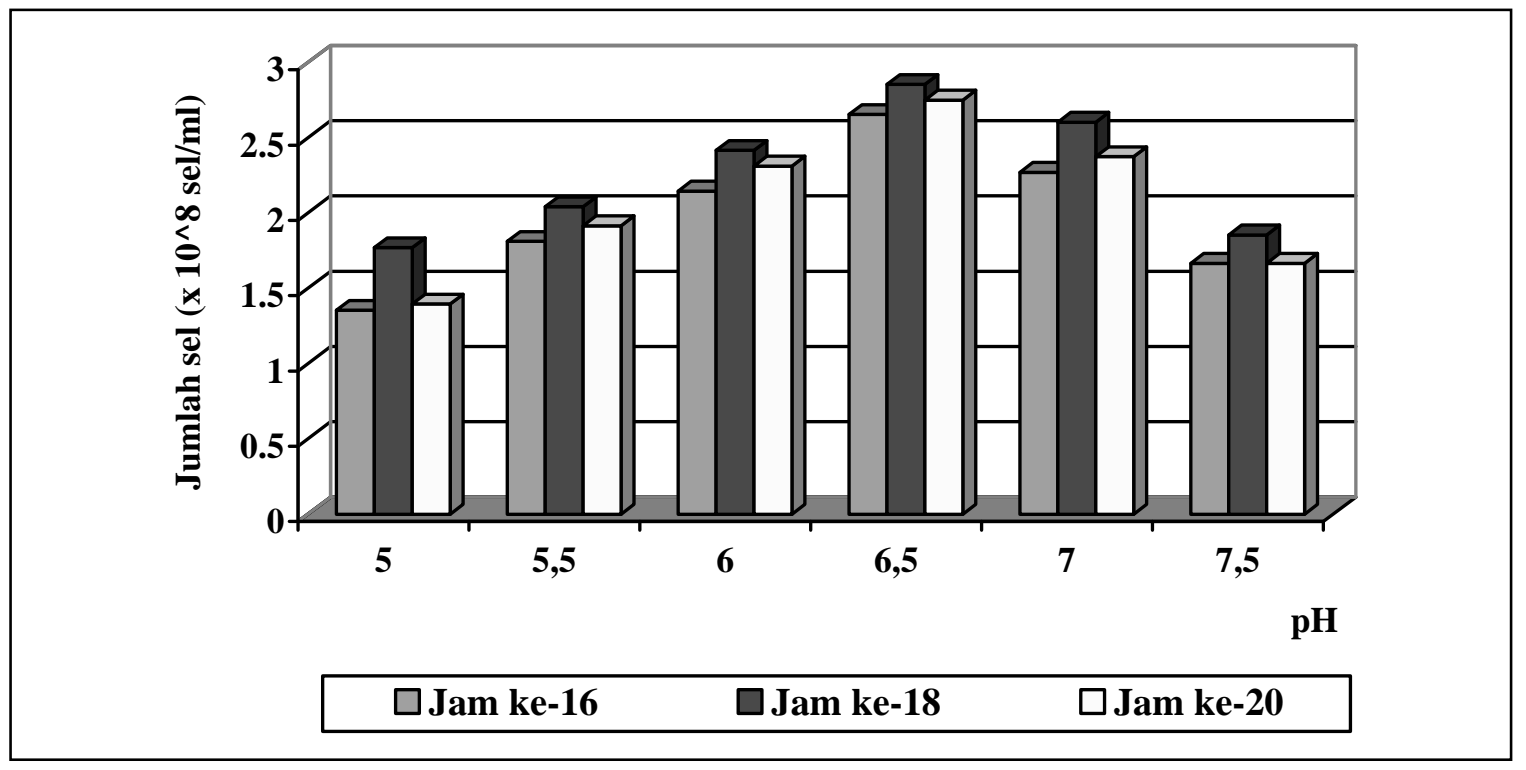

Gambar 3. Jumlah sel pada variasi pH awal medium selama fase stasioner (jam ke-16, 18 dan 20). 


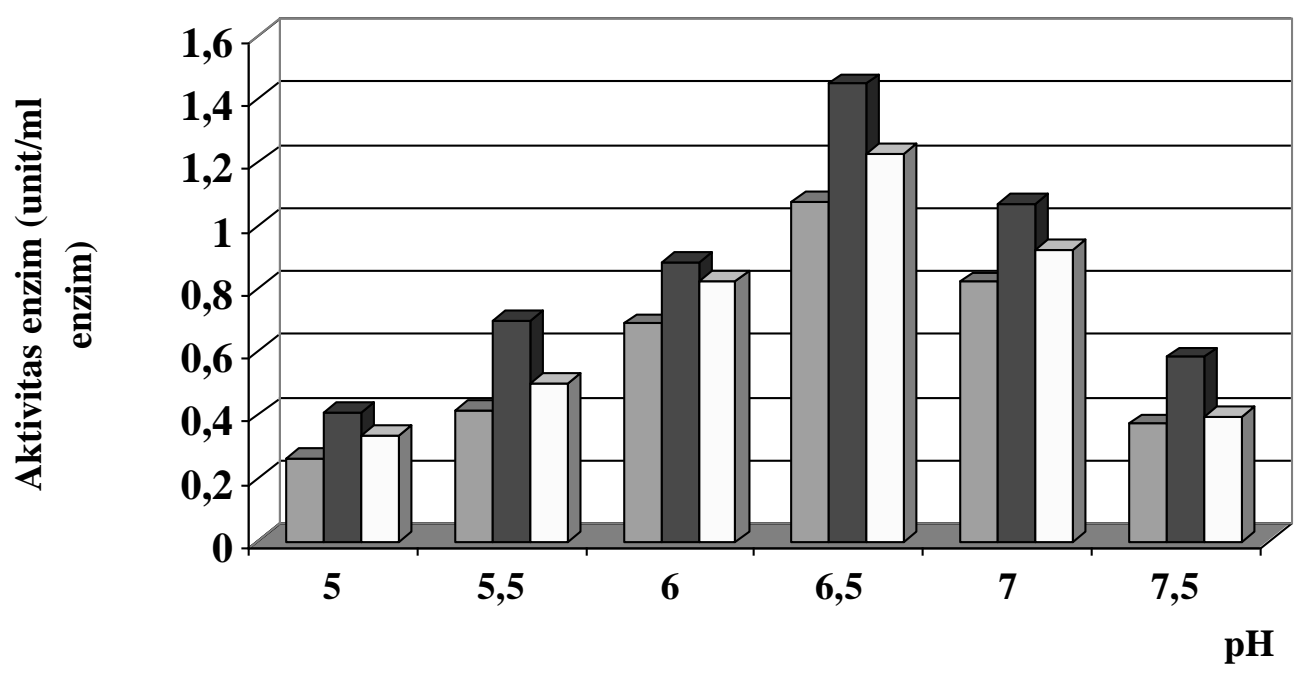

$\square$ Jam ke-16

$\square$ Jam ke-18

$\square$ Jam ke-20

Gambar 4. Aktivitas $\alpha$-amilase yang diproduksi pada variasi $\mathrm{pH}$ awal medium selama fase stasioner (jam ke-16, 18 dan 20).

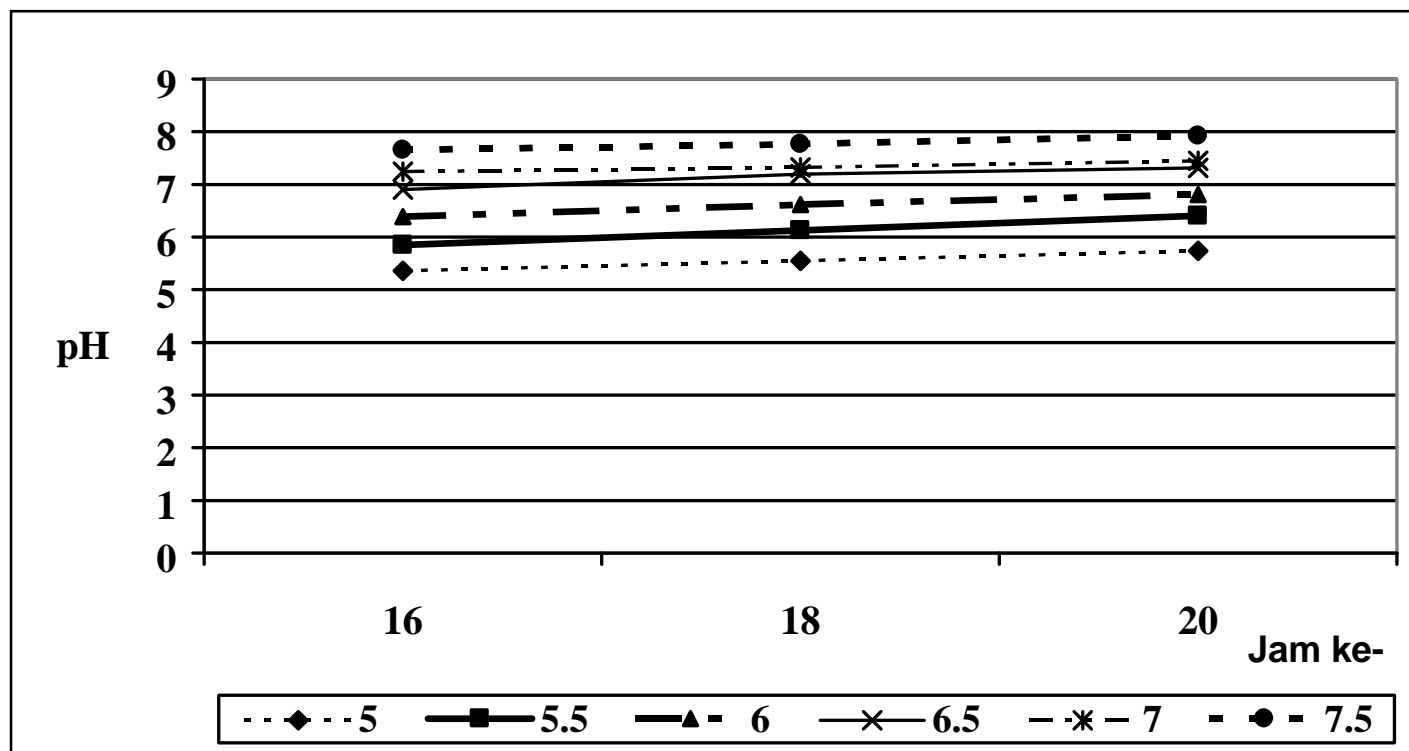

Gambar 5. Perubahan $\mathrm{pH}$ medium pertumbuhan pada variasi $\mathrm{pH}$ awal medium selama fase stasioner (jam ke-16, 18 dan 20). 


\section{Kesimpulan dan Saran}

\begin{abstract}
Berdasarkan hasil penelitian dapat diambil beberapa kesimpulan. Pertama, pertumbuhan sel $B$. amyloliquefaciens dalam medium yang ditambah pati jagung cenderung lambat. Kedua, perlakuan $\mathrm{pH}$ awal medium akan mempengaruhi jumlah sel dan produksi $\alpha$-amilase pada waktu inkubasi selama fase stasioner. Ketiga, jumlah sel dan aktivitas $\alpha$ amilase yang diproduksi mencapai optimum pada $\mathrm{pH}$ 6,5 dan jam ke-18, dengan jumlah sel sebesar $2,8542 \times 10^{8} \mathrm{sel} / \mathrm{ml}$ dan produksi $\alpha$ amilase sebesar 1,4467 unit $/ \mathrm{ml}$.

Berdasarkan hasil penelitian ini juga perlu dilakukan penelitian lebih lanjut mengenai pengaruh kombinasi $\mathrm{pH}$ dan suhu untuk produksi $\alpha$-amilase $B$. amyloliquefaciens, dan perlu dilakukan penelitian mengenai konsentrasi pati jagung yang optimum untuk pertumbuhan sel dan produksi $\alpha$-amilase $B$. amyloliquefaciens.
\end{abstract}

\section{Daftar Pustaka}

Achi, O.K. and Ngoku-Obi, A.N.U., 1992. Short Communication : Production of Raw Starch Saccharifying Amylase by Bacillus alvei Grown on Different Agricultural Substrates. World J. Microbiol. and Biotech 8: 206-207.

Crueger, W. and Crueger, A., 1990. Biotechnology A Textbook of Industrial Microbiology. Sinauer Associates, Inc., Sunderland.

Dirnawan, H., Suwanto, A. and Purwadaria, T., 2000. Eksplorasi Bakteri Termofil Penghasil Enzim Hidrolitik Ekstraseluler dari Sumber Air Panas Gunung Pancar. Hayati 7 (2): 52 - 55.

Dobreva, E., Ivanova, V. and Emanuilova, E., 1994. Effect of Temperature on Some Characteristics of Termostable $\alpha$-Amylase from Bacillus licheniformis. World J.Microbiol. and Biotech. 10 : $547-550$.

Fisher, S.H. and A.L.Sonenshein. 1991. Control of Carbon and Metabolism in Bacillus subtilis. Ann.Rev.Microbiol. 45: 107 - 135.

Frost, G.M. and Moss, D.A., 1987. Production of Enzymes by Fermentation. In : Kennedy, F. (Eds.). Biotechnology. Volume 7a. VCH Publishers. Germany.
Garret, R.H. and Grisham, C.M., 1995. Biochemistry. Saunders College Publishing. USA.

Gibson, T. and Gordon, R.E., 1975. Bacillaceae. In : Buchanan, R.E. and N.G. Gibbons (Eds.). Bergey's Manual of Determinative Bacteriology. $8^{\text {th }}$ ed. The Williams and Wilkins Company. Baltimore. USA.

Ginting, E.L., 2003. Isolasi dan Karakterisasi Enzim Amilolitik dari Bakteri Termofilik Perairan Pantai Likupang, Sulawesi Utara. J. Lasallian 2(1): 47 54.

Kulp, K., 1975. Carbohydrates. In Enzyme in Food Processing, Reed, G. (ed.).. $2^{\text {nd }}$ ed. Academic Press. USA.

Logan, N.A. and Turnbull, P.C.B., 1999. Bacillus and Recently Derived Genera. In : Murray, P.R., E. Jo Baron, M.A. Pfaler, F.C. Tenover and R.H. Yolken (Eds.). Manual of Clinical Microbiology. $7^{\text {th }}$ ed., ASM Press. USA.

Madigan, M.T., Martinko, J..M. and Parker, J., 2000.. Brock Biology of Microorganism. $9^{\text {th }}$ ed., Prentice Hall International Inc., New Jersey.

Mamo, G. and Gessesse, A., 1999. Purification and Characterization of Two Raw-Starch-Digesting Termostable $\alpha$-Amylases from A Thermophilic Bacillus. Enzymes and Microb. Tech. 25: 433 438.

Moat, A.G. and Foster, J.W., 1988. Microbial Physiology. $2^{\text {nd }}$ ed. John Wiley and Sons, Inc., USA.

Mubarik, N.R., Damayanti, E. dan Listyowati, S., 2003. Isolasi dan Karakterisasi Amilase dari Kapang Alkalotoleran Asal Limbah Cair Tapioka. Biota. 7(1): $1-7$.

Mulyadi, 1990. Analisis Makromolekul. PAU Bioteknologi UGM. Yogyakarta.

Priest, F.G., Goodfellow, M., Shute, L.A. and. Berkeley, R.C.W., 1987. Bacillus amyloliquefaciens sp. nov., nom. rev. International J. of System. Bacteriol. 33: 69 - 71 .

Riswahyuli, 2000. Pengaruh Kombinasi Kation dan Anion Terhadap Aktivitas $\alpha$-Amilase Aspergillus oryzae. Naskah Skripsi S-1. Fakultas Biologi Universitas Atma Jaya Yogyakarta. Yogyakarta.

Whitaker, J.R., 1972. Principles of Enzymology for The Food Sciences. Marcel Dekker, Inc., New York.

Wibowo, D., 1989. Bahan Pengajaran Mikrobiologi Industri. PAU Pangan and Gizi UGM. Yogykarta. 